\title{
Association of angiotensin converting enzyme gene (I/D) polymorphism with hypertension and type 2 diabetes
}

\author{
Zarouk WA ${ }^{1}$, Hussein $\mathrm{IR}^{1}$, Esmaeil NN${ }^{1}$, Raslan $\mathrm{HM}^{2}$, Reheim $\mathrm{HAA}^{3}$, Moguib $\mathrm{O}^{2}$, \\ Emara NA ${ }^{4}$, Aly AA ${ }^{4}$, Hamed $\mathrm{M}^{4}$
}

\author{
Molecular Genetic and Enzymology Department, National Research Centre, Cairo, Egypt. \\ w_zarouk@yahoo.com
}

\begin{abstract}
Objectives: This study was conducted to determine the association of insertion/deletion (I/D) polymorphism of the ACE gene in hypertensive and T2DM subjects in Egyptian population. Background: The deletion (D) allele of the angiotensin-converting enzyme (ACE) gene has been studied in relation to hypertension and type 2 diabetes mellitus (T2DM) with contradictory results which might be due to ethnic and geographical variations. Methods: A total of 85 subjects participated in this study; hypertension (Group 1); type 2 diabetes mellitus (Group 2) and controls (Group 3). Written informed consent was obtained. for each subject: age, sex, diabetes duration and the drugs used, blood pressure (systolic and diastolic), and lipid profile. Genotyping was performed by polymerase chain reaction (PCR).

Results: The frequency of DD genotype was significantly higher in hypertensive (60\%) and diabetic patients $(68 \%)$ compared to controls $(33.3 \%)(p=0.04, p=0.01$ respectively). The DD genotype (vs DI and II genotype) in the hypertensive and diabetic groups is associated with increased risk of hypertension and/or diabetes. $\mathrm{OR}=3.00 ; 95 \%, \mathrm{Cl}=0.993-9.067 ; \mathrm{OR}=4.250 ; 95 \%, \mathrm{Cl}=1.234-14.63$ respectively). The $\mathrm{D}$ allele was more frequent in hypertensive $(77.5 \%)$ and diabetic patients $(82 \%)$ compared to controls $(52.4 \%)(p=0.004$ and 0.002 respectively). The $\mathrm{D}$ allele (vs the I allele) is associated with increased risk of hypertension and diabetes $\mathrm{OR}=3.13,95 \% \mathrm{Cl}=1.405-6.978 ; \mathrm{OR}=4.14,95 \% \mathrm{Cl}=1.615-10.622$ respectively).

Conclusion: The DD genotype and the D allele are associated with hypertension and type 2 diabetes in Egyptian patients (Tab. 5, Fig. 1, Ref. 32). Full Text in free PDF www.bmj.sk.

Key words: angiotensin converting enzyme, polymorphism, type 2 diabetes, hypertension.
\end{abstract}

Hypertension and diabetes are a major public health burden worldwide and have been classified as a global epidemic. Evidence from the Egyptian Hypertension Project (20) revealed that the prevalence of hypertension in Egypt is among the highest in the world; approximately $60 \%$ of individuals above the age of 60 years suffer from hypertension. The steady growth in the number of elderly patients with hypertension in Egypt means that the country will face a serious national problem by the year 2020, when it can expect to deal with about 18 million elderly hypertensives $(22,23)$. Individuals with type 2 diabetes and hypertension are at markedly increased risk of cardiovascular morbidity and in a considerable cause of premature mortality, a situation that is likely to worsen, particularly in low and middle income countries (29).

${ }^{1}$ Molecular Genetic and Enzymology Department, National Research Centre, Kairo, Egypt, ${ }^{2}$ Internal Medicine Department, National Research Centre, Kairo, Egypt, ${ }^{3}$ Internal Medicine Department, Kasr El Aini Hospital, and ${ }^{4}$ Clinical and Chemical Pathology Department, National Research Centre, Kairo, Egypt

Address for correspondence: WA Zarouk, MD, National Research Centre, El Tahir St, El Dokki 12622, Cairo, Egypt

Acknowledgement: The authors thank Dr. Alaa El Deen Gamal, Molecular Genetics and Enzymology Department and Dr. Mostafa Ibrahim Mostafa, Oro-dental Genetics Department, National Research Centre, Cairo, Egypt, for manuscript revision. All authors have declared no conflict of interest.
The renin-angiotensin-aldosterone system (RAAS) is an important system in regulating blood pressure and electrolyte balance. Genes encoding components of the RAAS have been proposed as candidate genes that determine genetic predisposition to hypertension, diabetes and the risk of developing cardiovascular complications. Among the multiple genetic polymorphisms described, and possibly playing an active role in the pathogenesis of hypertension and cardiovascular disease is the angiotensin-converting enzyme (ACE) insertion/deletion (I/D) polymorphism. (24).

The ACE gene is mapped to chromosome 17q23 and is encoded by a $21 \mathrm{~Kb}$ gene that consists of 26 exons and 25 introns. (11). The insertion/deletion (I/D) polymorphism of ACE is characterized by the presence (insertion) or absence (deletion) of a 28 bp Alu repeat sequence in intron 16 producing three genotypes (II homozygote, ID heterozygote and $D D$ homozygote). Although the I/D polymorphism is located in a non-coding region (i.e. intron) of the ACE gene, several investigators have found that the $D$ allele is related to increased activity of ACE in serum $(30,31)$. However, previous reports concerning the link between I/D polymorphism of ACE gene and hypertension and type 2 diabetes revealed contradictory results. Moreover, various reports were published suggesting inter-ethnic variations in the frequency of allelic forms of the ACE genes. The presence or absence of an observed association in any ethnic, racial or geographic population 
may be related to a number of other factors including gene-gene and gene-environmental interactions $(28,2)$.

This study was initiated to elucidate the possible association between the I/D polymorphism in hypertensive and diabetic Egyptian patients

\section{Subjects and methods}

A total of 64 patients were recruited from outpatient clinic of Medical Services Unit at National Research Centre and from Kasr El Aini hospital, from February 2008 to December 2008. The patients were divided into two groups: group1 consisted of 40 patients with essential hypertension and group 2 consisted of 24 patients with type 2 diabetes. Twenty-one healthy individuals were collected randomly and served as controls. Patients with symptoms or signs suggesting secondary causes of hypertension or diabetes were excluded from the study. Written informed consent was obtained from all the subjects who participated in this study. All patients and controls were subjected to detailed history and information was obtained on demographic characteristics and medical history of all patients concerning history and duration of diabetes, hypertension and medications. Thorough physical examination was done for all subjects. Controls did not have any abnormalities regarding their physical examination, blood pressure, family history of hypertension or diabetes.

Hypertension was defined as a mean systolic blood pressure (SBP) $\geq 140 \mathrm{mmHg}$, mean diastolic blood pressure (DBP) $\geq 90$ $\mathrm{mmHg}$ or taking antihypertensive therapy. Type 2 diabetes was diagnosed according to WHO criteria (1).

Laboratory investigations in the form of lipid profile and fasting blood sugar and determination of ACE gene I/D polymorphism were done for all patients and controls.

\section{Laboratory methods}

\section{Sample collection and biochemical analysis}

Four to five milliliters of blood samples were collected from the peripheral blood leukocytes into EDTA tube (Becton Dickinson, NJ, USA) by a qualified phlebotomist. Plasma was separated from the blood by centrifugation method and stored at -20 ${ }^{\circ} \mathrm{C}$, Plasma samples were analyzed on a Autoanalyser (Hitachi, Germany) using kits supplied by Roche Diagnostics (Mannheim, Germany) to determine the level of triglycerides (TG), high density lipoprotein cholesterol (HDL-C) and total cholesterol (TC). Low density lipoprotein cholesterol (LDL-C) was calculated by Friedewald formula. Lipid profiles were classified under the category of The Third Report of the National Cholesterol Education Program guidelines.

Genotyping methods; DNA isolation and determination of ACE genotypes

Genomic DNA was extracted from peripheral blood using a salting-out technique; DNA isolation kit, (Qiagen) (25). The purity of extracted DNA was checked. ACE I/D polymorphism was performed by polymerase chain reaction (PCR) using the following flanking primer pair: forward; 5'- CTG GAG ACC ACT CCC ATC CTT TCT3', reverse 5'-GAT GTG GCC ATC TTC GTC AGAT-3'.

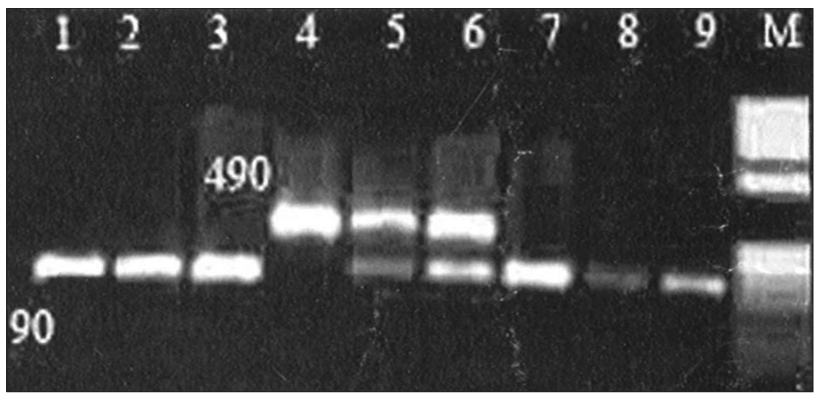

Fig. 1. Detection of I/D polymorphism of ACE gene in $2 \%$ agarose gel electrophoresis: Lanes 1, 2, 3, 7, 8 and 9 show homozygous DD genotype; lane 4, homozygous II genotype; lanes 5 and 6 show heterozygous ID genotype of I/D polymorphism. M represents a $\Phi 174$ bp DNA ladder.

PCR amplification was performed with a 25 ul reaction mixture that contained $0.22 \mathrm{ug}$ genomic DNA, 20 pmol of each primer, 4 $\mathrm{mmol} / \mathrm{L}$ each dNTP, $2 \mathrm{mmol} / \mathrm{L} \mathrm{MgCl} 2,1 \times$ Taq buffer and 1 unit of Taq DNA polymerase. The PCR cycling conditions were carried out on an thermal Cycler with an initial denaturation step of 5 minutes at $94{ }^{\circ} \mathrm{C}$, followed by 30 cycles of denaturation at $94{ }^{\circ} \mathrm{C}$ for 30 seconds, annealing at $58{ }^{\circ} \mathrm{C}$ for 1 minute and extension at $72{ }^{\circ} \mathrm{C}$ for 2 minutes, followed by a final extension for 5 minutes at $72{ }^{\circ} \mathrm{C}$ before the storage of the samples at $4{ }^{\circ} \mathrm{C}$. PCR products were separated by agarose gel electrophoresis (Promega, Madison, USA) performed in Origins electrophoresis. DNA fragments were stained in ethidium bromide and visualized under UV light. The DNA product was a $190 \mathrm{bp}$ fragment in case of deletion (D allele), and a $490 \mathrm{bp}$ fragment in the presence of insertion (I allele). Thus the PCR fragments showed three genotypes after electrophoresis: a 490 bp band (II), a 190 bp band (DD), and both a 490 and a 190 bp band (ID) Fig (1).

\section{Statistical analysis}

Statistical analysis was carried out using SPSS software version 10 for Microsoft Windows. Quantitative data were presented as mean $\pm \mathrm{SD}$ and qualitative data as frequency and percentage. All tests were two -sided and $\mathrm{p}<0.05$ was considered statistically significant. Difference between group means was tested by the student's t-test and differences in proportions were assessed by the chi-square test. Allelic frequencies were calculated by gene counting method. Risk estimate was done by odds ratio (OR) with $95 \%$ confidence interval $(95 \% \mathrm{CI})$

\section{Results}

\section{Baseline characteristics}

Among 64 patients included in the study, 40 patients had hypertension (group1) and 24 patients had type 2 diabetes (group 2 ). The hypertensive patients were 19 men (47.5\%) and 21 women $(52.5 \%)$, their mean age: $57.1 \pm 8.9$ years. The diabetic patients were $12(50 \%)$ men and $12(50 \%)$ women, their mean age: $49.39 \pm 12.78$ years. The controls (group3) consisted of 21 healthy individuals, $11(52.38 \%)$ men and $10(47.61 \%)$ women, their mean age: 
Tab. 1. Demographic, clinical and laboratory data of all subjects.

\begin{tabular}{|c|c|c|c|}
\hline Parameters & Hypertensives $(n=40)$ & diabetics $(n=24)$ & controls $(n=21)$ \\
\hline Sex (male,female) & 19,21 & 12,12 & 11,10 \\
\hline Age,years (mean $\pm \mathrm{SD})$ & $57.1 \pm 8.9$ & $49.39 \pm 12.78$ & $46.4 \pm 14.3$ \\
\hline $\mathrm{SBP}, \mathrm{mmHg} \quad($ mean $\pm \mathrm{SD})$ & $164.97 \pm 23.12$ & $131.56 \pm 12.08$ & $126.14 \pm 8.77$ \\
\hline $\mathrm{DBP}, \mathrm{mmHg}($ mean $\pm \mathrm{SD})$ & $99.18 \pm 11.65$ & $82.6 \pm 8.77$ & $78 \pm 7.17$ \\
\hline $\mathrm{TC}, \mathrm{mg} / \mathrm{dl}(\mathrm{mean} \pm \mathrm{SD})$ & $185 \pm 43.61$ & $206.64 \pm 60.18^{*}$ & $158.55 \pm 53.20$ \\
\hline $\mathrm{TG}, \mathrm{mg} / \mathrm{dl}($ mean $\pm \mathrm{SD})$ & $152.66 \pm 66.61 *$ & $178.16 \pm 109.32 *$ & $99 \pm 51.22$ \\
\hline LDL-C, mg/dl (mean \pm SD) & $124.5 \pm$ & $132.10 \pm .46 .41$ & $109.71 \pm 34.56$ \\
\hline
\end{tabular}

TC: total cholesterol, TG: triglycerides, LDL: low density lipoprotein, HDL: high density lipoprotein, *: significant difference with controls

Tab. 2. Genotype distribution in hypertensive patients and control group.

\begin{tabular}{llll}
\hline ACE genotype & $\begin{array}{l}\text { Hypertensives } \\
(\mathrm{n}=40)\end{array}$ & $\begin{array}{l}\text { Controls } \\
(\mathrm{n}=21)\end{array}$ & P value \\
\hline DD n (\%) & $24(60)$ & $7(33.3)$ & $0.048^{*}$ \\
DI n (\%) & $14(35)$ & $8(38.1)$ & 0.81 \\
II n (\%) & $2(8.3)$ & $6(28.6)$ & 0.07 \\
\hline *p is significant & & &
\end{tabular}

Tab. 3. Genotype distribution in diabetic patients and control groups.

\begin{tabular}{llll}
\hline ACE genotype & $\begin{array}{l}\text { Diabetics } \\
(\mathrm{n}=25)\end{array}$ & $\begin{array}{l}\text { Controls } \\
(\mathrm{n}=21)\end{array}$ & P value \\
\hline DD n (\%) & $17(68)$ & $7(33.3)$ & $0.019^{*}$ \\
DI n (\%) & $7(28)$ & $8(38.1)$ & 0.467 \\
II n (\%) & $1(4)$ & $6(28.6)$ & 0.021 \\
\hline
\end{tabular}

${ }^{*} \mathrm{p}$ is significant

Tab. 4. Allele frequency in hypertensive patients and controls.

\begin{tabular}{llll}
\hline ACE allele & $\begin{array}{l}\text { Hypertensive } \\
(\mathrm{n}=40)\end{array}$ & $\begin{array}{l}\text { Controls } \\
(\mathrm{n}=21)\end{array}$ & P value \\
\hline $\mathrm{Dn}(\%)$ & $62(77.5)$ & $22(52.4)$ & $0.004^{*}$ \\
$\mathrm{In}(\%)$ & $18(22.5)$ & $20(47.6)$ & $0.004^{*}$ \\
\hline
\end{tabular}

${ }^{*} \mathrm{p}$ is significant

Tab. 5. Allele frequency in diabetic patients and controls.

\begin{tabular}{llll}
\hline ACE allele & $\begin{array}{l}\text { Diabetic } \\
(\mathrm{n}=25)\end{array}$ & $\begin{array}{l}\text { Controls } \\
(\mathrm{n}=21)\end{array}$ & P value \\
\hline $\mathrm{D} n(\%)$ & $41(82)$ & $22(52.4)$ & $0.002^{*}$ \\
$\mathrm{In}(\%)$ & $9(18)$ & $20(47.6)$ & $0.002^{*}$ \\
\hline
\end{tabular}

${ }^{*} \mathrm{p}$ is significant

$46.4 \pm 14.3$ years. Serum triglycerides were higher in diabetic and hypertensive patients compared to controls $(\mathrm{p}=0.002, \mathrm{p}=0.02$ respectively) and total cholesterol was significantly higher in diabetic patients compared to controls) $\mathrm{p}=0.003$ ). The baseline characteristics of all the subjects enrolled in this study are shown in Table 1.

\section{Genotyping results}

Genotype distribution in hypertensive, diabetic patients and controls are presented in Table 2 and 3 . The frequency of DD genotype was significantly higher in hypertensive $(60 \%)$ and diabetic patients (68\%) compared to controls (33.3\%).

The DD genotype vs II genotype in the hypertensive and diabetic groups is associated with increased risk of hypertension and/or diabetes $(\mathrm{OR}=3 ; 95 \% \mathrm{CI}=0.993-9.067, \mathrm{OR}=4.25 ; 95 \%$ $\mathrm{CI}=1.23-14.63)$.

Table 4 and 5 show the allele frequency in hypertensive patients, diabetic patients and controls. The $\mathrm{D}$ allele was more frequent in hypertensive and diabetic patients compared to controls and the I allele is more frequent in controls than in patients with diabetes or hypertension.

The D allele vs the I allele is associated with increased risk of hypertension and diabetes (OR: 3.139; $95 \%$ CI: 0.1405-6.97 and $\mathrm{OR}=4.14 ; 95 \% \mathrm{CI}=1.615-10.62$ respectively)

There was no significant difference in genotype distribution or in allele frequency between hypertensive and diabetic patients. Considering the effect of gender on ACE genotype; no significant difference was found between males and females.

\section{Discussion}

The renin-angiotensin-aldosterone system (RAAS) is an important system in regulating blood pressure and electrolyte balance. RAAS gene polymorphisms have been extensively studied to determine the genetic susceptibility to hypertension. It also plays an important role in the pathogenesis of type 2 diabetes as RAAS blockade reduces insulin resistance. (21). An increased plasma and serum ACE level is genetically determined by I/D polymorphism of the ACE gene. The DD genotype is associated with higher ACE expression and activity and therefore might predispose individuals to hypertension and/or type $2 \mathrm{DM}$ and their complications (31). In this study, we found that DD genotype and the D allele of the ACE gene were strongly associated with hypertension and type 2 diabetes compared to healthy individuals, and they confer increased risk of hypertension and type 2 diabetes. Studies of the association between DD genotype and hypertension and type 2 diabetes showed conflicting results. Hsieh and colleagues and Feng and colleagues (2002) showed significant positive associations between ACE DD genotypes and presence of type $2 \mathrm{DM}$. Two recent studies, one conducted in Iranian patients and the other in Malysian patients showed increase frequency of DD genotype as well as D allele in diabetic and in hypertensive patients in comparison to the control group (26). On the other hand, several studies failed to reveal such correlation such as the study of Bhavani and colleagues (2005) who did not found a positive correlation between the DD genotype of ACE gene polymorphism and hypertension. Study on Turkish population found no significant association between ACE gene polymorphism and hypertension in diabetics (17). In Tunisian type 
2 diabetic patients there was no significant statistical difference between the genotype distribution and allele frequencies of the ( I/D ) polymorphism (2) and the study carried out by Grammer and colleagues (2006) in large number of Caucasian population , showed that the genotypes ACE II ,ID, DD occurred at similar frequencies in patients with type 2 diabetes mellitus compared to non-diabetic individuals. The observed controversies may be due to ethnic and geographic differences. A study comparing Caucasians and Afro-Caribbeans showed that DD polymorphism is associated with essential hypertension in Afro-Caribbean but not in European descent (4).

The ACE D allele is associated with higher serum ACE levels and increased conversion of angiotensin I to angiotensin II in white populations (32). Previous studies suggest that ethnicity modulates the relationship between the ACE I/D genotype and serum ACE activity. For example, Bloem and colleagues (1996) confirmed the relationship between the number of ACE D alleles and increasing serum ACE activity in whites but found no correlation between the ACE I/D genotype and serum ACE in blacks. In contrast, Forrester and colleagues 1997 reported a relationship between the ACE I/D polymorphism and serum ACE in individuals of African descent, similar to that previously reported in whites. However, in our study we did not assess the ACE levels.

The increased risk of diabetes with the D/D genotype may be explained by the previous report that low ACE activity increased insulin stimulated hexone transport in adipocytes, and insulin suppression of nonesterified fatty-acid flux (18). Higher ACE decreases glucose utilization in skeletal muscles during exercise, and ACE inhibitors increase insulin sensitivity, glucose transporter GLUT-4 synthase activity and hexokinase activity (10). As a result of these findings, high ACE activity, namely the ACE DD genotype, seems to increase the risk of impaired glucose metabolism or diabetes mellitus (DM). Also previous studies have shown that ACE inhibitors may improve glucose utilization and suppress hepatic glucose production $(27,3)$. The angiotensin converting enzyme catalyses the conversion of angiotensin-I to the angiotensin II and it also inactivates bradykinin, a potent vasodilator (21). Angiotensin is a proinflammatory and pro-oxidant, thus causing cellular toxicity and apoptosis and studies have demonstrated that chronic low grade systemic inflammation can predict the future risk of impaired glucose tolerance and type-2 diabetes mellitus (8).

The $\mathrm{D} / \mathrm{D}$ genotype is not only a risk factor for hypertension and diabetes but it is also associated with their complications. Recent study reported that $\mathrm{D}$ allele may increase the risk of cardiovascular disease by facilitating the development of left ventricular hypertension, microalbuminuria and low HDL cholesterol, especially among men (7). Dell'omo and colleagues, 2006 found that the D allele in hypertensive patients poses a higher risk for microalbuminuria and treatment with ACE inhibitors produces a greater reduction in microalbuminuria in hypertensive patients homozygous for the I allele. Several studies reported the association between the D/D genotype and diabetic nephropathy $(30,15)$. Fava and colleagues 2001 reported that the DD genotype of the ACE polymorphism predicts a poorer outcome in type 2 diabetic patients with nephropathy and is also associated with a higher mortality rate.
Although our study sample was relatively small as compared with other epidemiological and association studies, the result of this study supports the hypothesis that the DD genotype has a strong association with HTN and type 2 diabetes and that ACE polymorphism plays an important role in the pathogenesis of these diseases. However, further studies with larger sample size are necessary to confirm the association of the I/D polymorphism of the ACE gene and further investigation is needed to understand the possible role of other polymorphisms of RAAS genes in relation to essential HTN and type 2 diabetes in Egyptians.

\section{References}

1. Alberti KG, Zimmet PZ. Definition, diagnosis and classification of diabetes mellitus and its complications. Part 1 diagnosis and classification of diabetes mellitus provisional report of a WHO consultation. Diabet Med 1998; 15: 539-553.

2. Arfa I, Abid A, Nouira S, Elloumi-Zghal S, Malouche S, Mannai I, Zorgati M, Benalaya N, Rebai A, Zouari B. Lack of association between the angiotensin- converting enzyme gene (I/D) polymorphism and diabetic nephropathyin Tunisian type 2 diabetic patients. Journal of Renin - Angiotensin - Aldosterone System 2008; 9 (1): 32-36.

3. Barbalic M, Skaric-Juric T, Cambien F. Gene polymorphisms of the renin-angiotensin system and early development of hypertension. Am J Hypertens 2006; 19: 837-842.

4. Barley G, Blackwod A, Miller M et al. Angiotensin converting enzyme gene I/D polymorphism, blood pressure and the rennin-angiotensin system in cauvasian and Afro-Caribbean peoles. J Hum Hypertens 1996; 10: 31-35.

5. Bhavani BA, Padma T, Sastry BKS, Krishna-Reddy N, Nausheen K. The insertion/deletion polymorphism of ACE gene increase the susceptibility to hypertension and/or diabetes. . Int J Hum Genet 2005; 5: 247 - 252.

6. Bloem LJ, Manatunga AK, Pratt JH. Racial difference in the relationship of an angiotensin I-converting enzyme gene polymorphism to serum angiotensin I-converting enzyme activity. Hypertension 1996; 27: 62-66.

7. Cardoso RL, Nogueira AR, Salis LH, Urmenyi TP, Silva R, MouraNeto RS, Pereira BB, Rondinelli, Silva NE. The association of ACE gene $\mathrm{D} / \mathrm{I}$ polymorphism with cardiovascular risk factors in a population from Rio de Janeiro. Brazilian Journal of Medical and Biological Research 2008; 41: 512-518.

8. Chmaisse HN, Jammal M, Fakhoury H, Fakhoury R. A study on the association between angiotensin-I converting enzyme I/D dimorphism and type-2 diabetes mellitus. Saudi J Kidney Dis Transpl 2009; 20 (6): $1038-1046$.

9. Dell'omo G, Penno G, Pucci L, Lucchesi D, Fotino C, Del Prato S et al. ACE gene insertion/deletion polymorphism modulates capillary permeability in hypertension. Clin Sci 2006; 111: 357-364.

10. Dietze GJ, Henriksen EJ. Angiotensin-converting enzyme in skeletal muscle: sentinel of blood pressure control and glucose homeostasis.. J Renin Angiotensin Aldosterone Syst 2008; 9 (2): 75-88.

11. Di Pasquale P, Cannizzaro S, Scalzo S. Cardiovascular effects of I/D angiotensin-converting enzyme gene polymorphism in healthy subjects. Findings after follow-up of six years. Acta Cardiol 2005; 60:427-435.

12. Fava S, Azzopardi J, Ellard S, Hattersley AT. ACE Gene Polymorphism as a Prognostic Indicator in Patients With Type 2 Diabetes and Established Renal Disease Diabetes Care 2001; 24: 2115-2120. 
13. Feng Y, Niu T, Xu X, Chen C, Li Q, Qian R et al. Insertion/deletion polymorphism of the ACE gene is associated with type 2 diabetes. Diabetes. 2002; 51:1986-1988.

14. Forrester T, McFarlane-Anderson N, Bennett FI, Wilks R, Cooper R, Rotimi C, Morrison L, Ward R. The angiotensin converting enzyme and blood pressure in Jamaicans. Am J Hypertens 1997; 10: 519-524.

15. Fujisawa T, Ikegami H, Kawaguchi Y, Hamada Y, Ueda H, Shintani M, Fukuda M, Ogihara T. Meta-analysis of association of insertion/ deletion polymorphism of angiotensin 1-converting enzyme gene with diabetic nephropathy. Diabetologia 1998; 41: 47-53.

16. Grammer TB, Renner W, Von Karger S, Boehm BO, Winkelmann BR, Maerz W. The angiotensin-1 converting enzyme I/D polymorphism is not associated with type 2 diabetesin individuals undergoing coronary angiography. (The Ludwigshafen Risk and Cardiovascular Health Study). Mol Genet Metab 2006; 88: 378-383.

17. Gunes HV, Ata N, Degirmenci I, Basaran A, Timuralp B, Dikmen M, Ustuner C, Kudaiberdieva G. Int J Clin Pract 2004; 58 (9): 838-843.

18. Hennes MM, O'Shaughnessy IM, Kelly TM, LaBelle P, Egan BM, Kissebah AH. Insulinresistant lipolysis in abdominally obese hypertensive individuals: role of the renin-angiotensin system. Hypertension 1996; 28: 120-126.

19. Hsieh MC, Lin SR, Hsieh TJ, Hsu CH, Chen HC, Shin SJ et al. Increased frequency of angiotensin- converting enzyme DD genotype in patients with type 2 diabetes in Taiwan. Nephrol Dial Transplant. 2000; 15: 1008-1013.

20. Appel LJ, Rizk HH, Helmy S, Mosley J, Ashour Z, El-Aroussy W, Roccella E, Whelton P. Cardiovascular risk factors in normotensive and hypertensive Egyptians. J Hypertens 2001; 19 (11): 1933-1940.

21. Kumar R, Singh VP, Baker KM. The intracellular renin-angiotensin system in the heart. Curr Hypertens Rep 2009; 11 (2): 104-110.

22. Lawes CM, Vander Hoorn S, Law MR, Elliott P, MacMahon S, Rodgers A. Blood pressure and the global burden of disease 2000. Part 1: estimates of blood pressure levels. J Hypertens 2006; 24 (3): 413-422.

23. Lawes CM, Vander Hoorn S, Rodgers A. International Society of Hypertension Global burden of blood-pressure-related disease, 2001. Lancet 2008; 371 (9623): 1513-1518.
24. Lee YJ, Tsai JCR. ACE gene insertion/deletion polymorphism associated with 1998 World Health Organization definition of metabolic syndrome in Chinese type 2 diabetic patients. Diabetes Care 2002; 25 (6): 1002-1008.

25. Marre M, Jeunemaitre X, Gallois Y, Rodier M, Chatellier G, Sert $\mathbf{C}$ et al. Contribution of genetic polymorphism in the renin-angiotensin system to the development of renal complications in insulin-dependent diabetes: Genetique de la Nephropathie Diabetique (GENEDIAB) study group. J Clin Invest 1997; 99: 1585-1595.

26. Nikzamir A, Nakhjavani M, Golmohamadi T, Dibai L. Association of Angiotensin-Converting Enzyme Gene Insertion/Deletion Polymorphism with Metabolic Syndrome in Iranians with Type 2 Diabetes Mellitus. Arch Iranian Med 2008; 11 (1): 3-9.

27. Sayed-Tabatabaei FA, Oostra BA, Isaacs A, van Duijn CM, Witteman JC, Scheen AJ. Prevention of type 2 diabetes mellitus through inhibition of the Renin-Angiotensin system. Drugs 2004; 64 (22): 2537-2565.

28. Singh PP, Naz I, Gilmour A, Singh M, Mastana S. Association of APOE (Hha1) and ACE (I/D) gene polymorphism with type 2 diabetes mellitus in North West India. Diabetes Res Clin Pract 2006; 74: 95-102.

29. Sousa RM, Ferri CP, Acosta D, Albanese E, Guerra M, Huang Y, Jacob KS, Jotheeswaran AT, Rodriguez JJ, Pichardo GR, Rodriguez MC, Salas A, Sosa AL, Williams J, Zuniga T, Prince M. Contribution of chronic diseases to disability in elderly people in countries with low and middle incomes: a 10/66 Dementia Research Group population-based survey. Lancet 2009; 28: 1821-1830.

30. Staessen JA, Wang JG, Ginocchio G, Petrov V, Saavedra AP, Soubrier F, Vlietinck R, Fagard R. The deletion/insertion polymorphism of the angiotensin converting enzyme gene and cardiovascular renal risk. J Hypertens 1997; 15: 1579-1592.

31. Stephens JW, Dhamrait SS, Cooper JA, Acharya J, Miller GJ, Hurel SJ et al. The D allele of the ACE I/D common gene variant is associated with type 2 diabetes mellitus in Caucasian subjects. Mol Genet Metab 2005; 84: 83-89.

32. Ueda S, Elliott HL, Morton JJ, Connell JM. Enhanced pressor response to angiotensin I in normotensive men with the deletion genotype (DD) for angiotensin-converting enzyme. Hypertension. 1995; 25 : 1266-1269. 